\title{
Facilitating Community Change: Lessons from Climate Adaptation to Guide Extension Engagement ${ }^{1}$
}

\author{
Martha Monroe and Annie Oxarart ${ }^{2}$
}

\section{Extension Addresses Community Issues: Planning for Climate Change Adaptation}

Extension agents work on many issues and at many levels to help improve individual, family, and community well-being in Florida. Because climate change is one of the biggest current issues and affects several aspects of society, Extension programming related to climate has increased in recent years. In some cases, agents are helping to communicate the science behind global warming or the causes of increases in greenhouse gas emissions. Some communities or industries are already focusing on mitigation-implementing strategies to reduce sources of greenhouse gases or to increase the amount of greenhouse gases being removed from the atmosphere, through carbon sequestration, for example.

In other cases where local impacts of our changing climate are being felt, community and business leaders may be asking how to reduce their risk in an uncertain future. This provides an opportunity for Extension agents to develop programs and processes that plan for adaptation. Adaptation responds to actual or expected climate changes by implementing strategies to reduce vulnerability to or gain benefits from climate change (IPCC 2014). Even though adaptation strategies may not address the causes of climate change, they present tangible ways for people to respond. Furthermore, they are most effective at the local level because they can be designed to match the specific context (Füssel 2007).

Climate-related changes are already underway (Box 1). In many places, farmers, health workers, urban planners, builders, ranchers, and forest landowners are adapting their typical practices to accommodate new conditions. Extension can help community leaders and those at risk become more aware, answer their questions, and navigate a transparent process to make decisions that will affect their future.

1. This document is FOR361, one of a series of the School of Forest Resources and Conservation Department, UF/IFAS Extension. Original publication date May 2020. Visit the EDIS website at https://edis.ifas.ufl.edu for the currently supported version of this publication. Martha Monroe, professor and associate director, School of Forest Resources and Conservation; and Annie Oxarart, program coordinator for Extension activities, School of Forest Resources and Conservation; UF/IFAS Extension, Gainesville, FL 32611.

2. Other contributors: Holly Abeels, UF/IFAS Extension Florida Sea Grant Agent, Brevard County; Wendy-Lin Bartels, assistant research scientist, Natural Resources Leadership Institute; Alicia Bradigan-Betancourt, director, UF/IFAS Extension Monroe County; Libby Carnahan, UF/IFAS Extension Florida Sea Grant agent, Pinellas County; Crystal Goodison, associate director, Geo-Plan Center, University of Florida; and Thomas Ruppert, climate and policy coordinator, UF/IFAS Extension Florida Sea Grant.

This booklet provides Extension faculty in Florida with useful strategies to help communities understand, discuss, evaluate, and recommend potential solutions to current and future problems. While much of the research behind these strategies has been conducted in the context of climate adaptations in vulnerable communities and ecosystems, such as coastal fisheries, rainfed agriculture, and floodplain cities, the principles that underlie these processes are universal. The same strategies and guidelines can be tailored for any issue that requires the public to become more informed, generate options, and understand advantages and disadvantages of various choices. In these situations, Extension agents can facilitate a process of thoughtful deliberation to help communities find common ground and move toward finding solutions.

The Institute of Food and Agricultural Sciences (IFAS) is an Equal Opportunity Institution authorized to provide research, educational information and other services

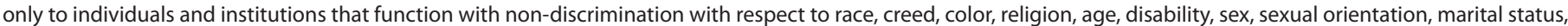

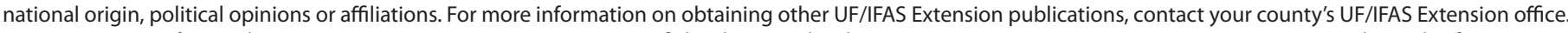
U.S. Department of Agriculture, UF/IFAS Extension Service, University of Florida, IFAS, Florida A \& M University Cooperative Extension Program, and Boards of County Commissioners Cooperating. Nick T. Place, dean for UF/IFAS Extension. 
Details on climate science and climate change abound (see Resources), but there has been less attention on the strategies and processes that Extension agents can use to help communities navigate adaptation decisions. This guide summarizes themes from a review of global adaptation projects and offers a few case studies to illustrate how Florida agents and specialists are supporting change.

\section{Box 1. Examples of Climate Impacts and Adaptations in Florida.}

Temperature and precipitation changes occur annually in Florida based on El Niño and La Niña shifts, which are examples of seasonal climate variability. Long-term projections for changes in Florida's climate are not as drastic as other states are likely to experience (see climate scenario projection maps to explore impacts by state) but could affect crops and native organisms that reside at the margin of their ranges. Adaptations are already in practice. In 2012, the average changes in the number of hot days and cold nights, as well as better data collection tools, prompted the US Department of Agriculture to change their plant hardiness zones, which can influence where certain crops are planted (https://planthardiness.ars.usda.gov/PHZMWeb). Row-crop producers pay close attention to temperature and precipitation forecasts and each year adapt decisions about cropping choice, timing of planting or harvesting, and soil and irrigation management (Bartels et al. 2012).

Predicted changes in temperature and carbon dioxide concentration are likely to increase growth rates of planted pines in most of the southeastern United States. Careful management of forest density and nutrition may enable forest landowners to mitigate insect and disease problems that may occur with accelerated growth rates and climate change while reaping some economic benefits from changing climate (Martin et al. 2017). Tree breeders may also be able to guide landowners to plan for change with longer time horizons by, for instance, selecting seedlings from parent trees that are currently doing well in a climate a bit farther south, knowing that in the years that these trees are alive, the climate shifts will make them more likely to thrive (http://pinemapdss.org).

Slight changes in climate are already resulting in widespread stressors that make organisms susceptible to pest attack. Prolonged drought, for instance, weakens pine trees and makes it easier for bark beetles to thrive. In former forestry stronghold British Columbia, for another example, $80 \%$ of the pines have been lost to bark beetle outbreaks facilitated by warm winters and dry summers. Pests that typically live in the tropics, such as in south Florida, are enjoying the warmer climate and are expanding their range. These pests could harm agriculture (e.g., citrus greening), native plants (e.g., tropical subterranean termite), and people (e.g., mosquitoes vectoring the Zika virus). Adaptations involve new strategies to monitor pests, new hybrid crops that are more resilient to either the climate changes or the pests, and new behaviors that prevent exposure to disease.

Changes in rainfall and temperature will also affect water availability in Florida. Rainfall is the source of Floridians' drinking water. If more rain falls during shorter, more intense storms, water may run off more quickly to the ocean, leaving less fresh water available for use. Researchers with the UF Water Institute are working with Florida utilities to improve water storage and allocation decisions to benefit both humans and aquatic ecosystems.

Climate change may affect the frequency and severity of storms—-both hurricanes in the South and blizzards in the North—or it may affect the impact of storms (Walsh and Webbles 2014). While communities cannot predict the extent of storm damage in advance, they can consider their emergency preparedness systems and plans. Coastal cities like Sarasota have conducted workshops to explore potential storm surge damage and recovery efforts and have realized that some emergency services could be damaged (Frazier, Wood, \& Yarnal 2010).

Mental, physical, and community health impacts of climate change are more likely as people respond to the physical impacts (e.g., wildfires, sea-level rise, drought) and impacts on human systems and infrastructure (e.g., transportation networks, crop production, energy systems). Individuals may feel hopeless and helpless, anxious, or stressed; incidence of substance abuse and domestic abuse may increase; and communities may become less stable. Heat-related illness may affect those who work outdoors, and tropical diseases may become more prevalent in Florida (Clayton et al. 2015).

The most significant change that is affecting the 35 counties along the coastline in Florida is sea-level rise, a product of melting land ice and thermal expansion of water. Sea water currently creeps into neighborhoods and stormwater drains during high tide along the Atlantic coast, and future projections are prompting a sweeping set of responsible adaptations to higher water levels: raising bridges and roadbeds, changing building codes and zones, replumbing storm drains, raising septic tanks, or connecting to sewer lines (http://www.southeastfloridaclimatecompact. org/?s=groundwater).

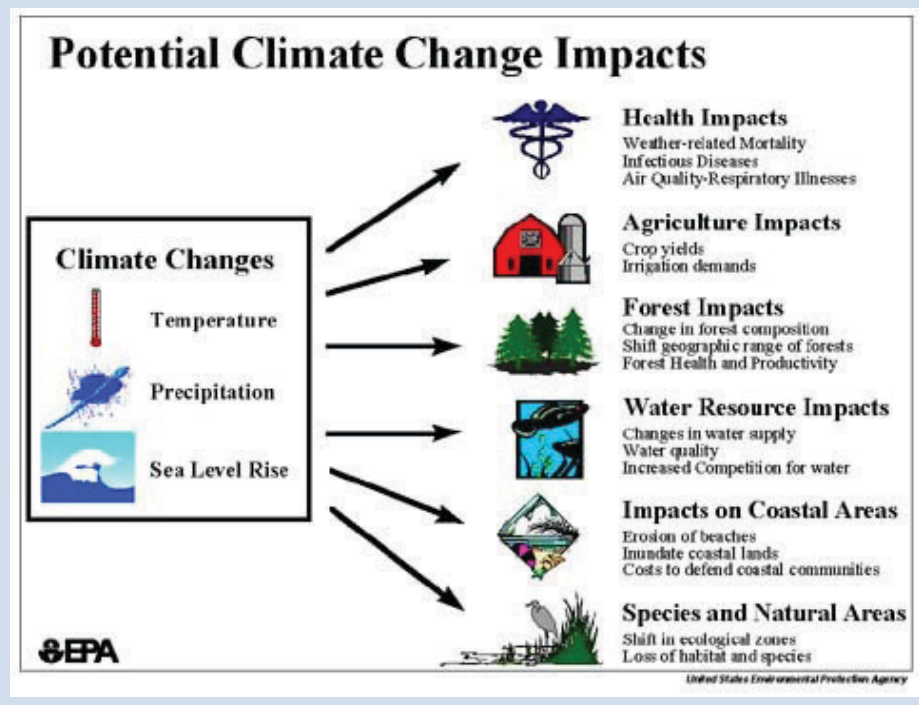




\section{Why Extension Should Help Communities Address Change, especially Climate Change}

We all know change is inevitable, but that doesn't make it easier to address. Avoidance is one reasonable coping strategy, particularly when there is disagreement about the causes of change and uncertainty about its expected impacts. If the extent of change is unknown, why bother to act now? However, many adaptation strategies can produce outcomes that are beneficial for both current and future conditions, and some communities are already taking advantage of climatic uncertainties by making changes that will improve their quality of life regardless of the future. For example, improving affordable housing, repairing bridges and roads, and investing in renewable energy are good strategies for a sustainable future, regardless of climate. In addition, when high-value resources are at risk, people might be willing to protect them despite the uncertainty, just like our fire and flood insurance policies (Luque et al. 2013).

The global nature of climate change might also justify non-action because people believe a few individuals or one community won't make a difference. In this case, people are confusing mitigating the extent of climate change with helping communities adapt to change. While it is challenging to determine how much local efforts to reduce carbon emissions influence overall reductions in atmospheric carbon, it is very easy to see how raising a roadbed prevents damage during high tide. Small adaptations can make a big difference to families and communities who are dealing with changes that affect their day-to-day decisions, property, and well-being.

Climate change is a complex issue made more challenging by its global scale, diffuse causes, and multiple threats. From a human perspective, just thinking about climate change is stressful. People tend to respond to threats by assessing the degree of impact (risk, severity, and vulnerability) and assessing the possible effects and responses to this impact, including personal and community responses (Reser and Swim 2011). How people respond is a function of their experience, their biases (especially underpreparing for disaster, believing technology will save us, and lacking experience with significant threat, see Meyer and Kunreuther 2017), the way their social group constructs and interprets the issue, and the degree to which they believe they are responsible to take action and/or capable of taking action. These insights can help Extension agents present information in ways that can be better understood and more relevant to lived experiences. Beginning with the acknowledgement that people have different opinions about climate science based on the news and priorities of their peers and leaders, Extension professionals can highlight the ways communities are adapting to potential and actual changes, and strengthen social networks and capacity for coping (Reser and Swim 2011).

\section{Why Adaptation Is a Valuable Approach}

One advantage to focusing on how communities can adapt to a global issue is that the scale of the change becomes manageable. Smaller problems require appropriately smaller solutions. When people stop thinking about global change and imagine just one local element of change, such as finding a hybrid variety for a vulnerable crop, or preventing mosquitoes from breeding in their neighborhoods, success is more likely. Downscaling the problem makes it easier to think about and allows people to explore creative solutions (Weick 1984).

Research suggests that the action of planning for change can increase an individual's well-being. Even when the dimensions of the change are uncertain, people prefer to know there is a plan for response, and they particularly appreciate being involved in creating those plans (Kaplan and Kaplan 2009; Rafferty and Griffin 2006). Extension can help engage people in this process and let others know a plan is being developed.

What makes some people embrace an opportunity for change while others can barely begin to think about it? One factor is resilience. Individuals, organizations, and communities can all exhibit varying levels of resilience. This can mean having inner strength to contend with problems as well as having access to networks, resources, and social capital that enable a community to plan for and recover from crisis. It also means being able to function in a new world. There are things we can do to become more resilient in the face of change and make the journey toward change less stressful, like acknowledging that things are changing and seeking supportive networks and resources to improve coping strategies (Sarkis 2017). In the context of communities adapting to climate changes, resilience means the capacity to find alternatives, avoid or deflect problems, or recover from an event.

Some agents have expressed concern about approaching the topic of climate change because the issue has been politicized. Extension agents will find it essential to carefully consider the objectives of their program, who will attend, 
and how the program will be advertised as they construct an agenda that leads to thoughtful and meaningful exchange (McNeeley and Lazrus 2014). As the examples in this guide from Thomas Ruppert, Holly Abeels, Wendy-Lin Bartels, Libby Carnahan, and Alicia Bradigan-Betancourt suggest, residents and community leaders are interested in learning and discussing options. They realize that the future may not mirror the past and want to be prepared (Box 2).
The Cooperative Extension Service has a long and successful history of local agents addressing local problems that have state and national significance. It also has a track record of both building skills to help people solve their own problems and using the best available science to offer practical and useful solutions. Both strategies are essential as Extension agents help communities navigate their challenges.

\section{Box 2. Florida Case Study: Satellite Beach Explores Sea-level Rise Issues.}

by Thomas Ruppert, Climate and Policy Coordinator, Florida Sea Grant

UF/IFAS Extension has assisted the barrier-island city of Satellite Beach for the past several years in understanding and planning for sea-level rise and has recently begun the management phase of adapting to sea-level rise. Since 2011, Florida Sea Grant coastal planning specialist Thomas Ruppert, Esq. has been consulting with the city of Satellite Beach on legal and policy issues raised by rising seas. Beginning in 2016, Florida Sea Grant has been collaborating with the city and other partners on a grant-funded team to develop detailed data and maps establishing vulnerability under multiple storm and sea-level-rise scenarios. The project team then worked with the city to deliver this information in public meetings that included time for discussion and an opportunity for the audience to suggest responses to the challenges of rising seas. Florida Sea Grant's coastal planning specialist provided an overview of adaptation and resilience policies being pursued by other local governments in Florida.

Based on the suggestions provided during this meeting, the team developed a survey instrument for the community to prioritize potential responses of the city to rising seas and storms. Extension was one of several partners in a public forum where city residents were encouraged to fill out the survey. With these survey results, the East Central Florida Regional Planning Council was able to provide the city of Satellite Beach with a prioritized list of responses desired by the city's citizens to threats such as erosion, storm surge, flooding, and loss of utilities/ power.

Survey responses indicated that citizens' top concern was loss of utilities/power, and the top suggestion to address this was placing utility lines underground. These results demonstrated the challenges and limitations of such an approach: the decision to put utility lines underground is not one the city of Satellite Beach has the power to make. However, the process also resulted in numerous suggestions that the city can implement, such as increasing building setbacks to address coastal erosion and surge vulnerabilities and increasing the capacity of stormwater systems to address flooding and sea-level rise. The process also resulted in the broader impact of mainstreaming discussions of sea-level rise among city residents. Survey results clearly demonstrated that most respondents feel it is imperative to address the challenges of erosion, utilities/power loss, flooding, and storm surge. This has allowed the city to continue to develop and implement policies designed to address flooding and sea-level rise, both now and in the future. Extension, through Florida Sea Grant, continues to play a critical role in the partnerships helping Satellite Beach move forward, including helping the city understand and address legal concerns and developing recommended policies for consideration by the city of Satellite Bea Beach.

\section{How to Help Communities with Adaptation Planning}

Extension faculty are uniquely positioned to help orchestrate or participate in a community adaptation planning process by engaging relevant government agencies, drawing on university expertise, facilitating information exchange among community members, and guiding a deliberative discussion process (Box 3). Extension, after all, offers a wealth of expertise in community education. Participants need both factual information and an opportunity to hear what other people think about that information. Both the information and the opinions about the information are essential, rather like the two rails that hold the rungs of a ladder. Remembering to provide both "rails" will help you build a program that provides information and discussion simultaneously. Some information is needed to ensure participants have the necessary background to create informed judgment. The process of discussion often leads to new questions and the need for more information. There is a limit to how much information people can absorb without time to process it through discussion, questions, and reflection. And climbing a ladder happens one rung at a time, giving agents a chance to add to each rail as they go! The CIVIC program (Community Voices, Informed Choices) has many resources to help agents explore this process.

This deliberative discussion process has a long history in New England's town hall meetings, where communities use it to arrive at good solutions. Some programs, like the National Issues Forums Institute, emphasize opportunities to discuss opinions without getting side-tracked by scientific information, which can be a source of division. In some scientific, complex problems, it may be helpful to invite the public to a meeting that enables experts to provide a basic amount of information and then answer questions from the audience (Monroe et al. 2009). This allows community members to build upon a base of knowledge with information that specifically meets their needs. Another possibility is for Extension to organize a series of informational 
programs, field tours, and demonstrations in concert with opportunities to discuss options and seek common ground.

The goal of deliberative discussions around climate adaptations is to understand the issues, evaluate areas of risk and concern, identify and assess potential solutions, and recommend actions. Deliberative discussions are the activity that Extension agents can use to help a community move forward with adaptation planning. They can involve the presentation of information, but the discussion portion primarily revolves around participants expressing their preferences and exploring alternatives. At the end of a discussion, the participants may be able to prioritize options and recommend strategies for the next step.

Community adaptation planning to address climate issues typically involves the following three phases (Moser and Ekstrom 2010):

\section{Understanding: During this phase, the community is} involved in identifying and learning about climate issues, impacts, and risks specific to their geographic area. They may assess their vulnerability and consider the priorities they have for the most valued components of the community. Community members may find it helpful to learn what other communities are doing as they seek relevant resources and imagine possibilities.

\section{Planning: This phase includes identifying, assessing,} and selecting strategies to address risks. It may begin by thinking about what could be changed and considering the resources involved in making that change. It will likely involve expanding the network of collaborators to access needed resources as the plan takes shape.

3. Management: This final phase includes implementing chosen actions, along with monitoring and evaluating their effectiveness. This would likely involve relevant agencies and organizations taking the lead on carrying out the changes, but if the community needs information and demonstrations to adopt these new actions, Extension could again play a key role in the process.

Because Extension faculty are mostly likely to start or enter an existing community effort during the understanding or planning phase, we focus on those two adaptation phases in this booklet. Table 1 provides a variety of objectives and strategies for additional program development during each phase.
Box 3. Florida Case Study: Economic Modeling for Citizen Engagement in Monroe County

by Alicia Bradigan-Betancourt, Monroe County Extension Director-Community Development Agent

In coastal counties, sea-level rise threatens infrastructure and community assets. Through economic modeling, communities can develop strategies for climate change adaptation. Extension agents led workshops from 2015-2017 using modeling paired with facilitation, deliberative discussion, and knowledge experts to engage Monroe County communities in planning for sea-level rise impacts. Economic modeling software mimics floods from storms and sea-level rise on community assets such as homes and businesses, then tallies the cumulative damages over time so communities can better understand the cost of adaptation. Each workshop series brought citizens together for 3 sessions over 3 weeks. At the first session, maps were provided by Extension to show low-lying areas and to determine vulnerability. Citizens discussed vulnerability, sea-level rise projections, and possible actions. They selected four adaptation actions and three sea-level rise projections to model for economic impact.

At the next session, returning citizens were provided economic data for each of the options developed with the software. Skilled facilitators and key experts helped participants deliberate the four options. The first option selected was "no action." Three "action" scenarios were selected: elevating and floodproofing buildings, building barriers close to the coast, and purchasing vulnerable properties through a voluntary buyout program. For each action, costs were determined by using tax assessment data. Modeling parameters (projections and geographic) were established by workshop participants through a keypad polling process. For the final workshop, the model was run with the four action scenarios, and the results were converted into benefit-cost ratios. Ratios greater than 1 represented an action that reduced more in damages than they cost to implement. The action that had the best benefitcost ratio was elevating and floodproofing buildings. The model predicted for every $\$ 1.00$ spent the avoided damages would range from $\$ 5.24$ to $\$ 15.28$, depending on sea-level rise projections and construction costs.

After looking at the model results and participating in the group discussions, participants voted that elevating and floodproofing buildings was their most preferred action and supported pursuing sources of funding to help private property owners do so. Importantly, the modeling results and community engagement process enabled Extension to provide the residents with the opportunity to participate in community planning.

Extension's role in providing research-based best practices can be expanded to allow for adaptive, community-driven response. It is the community who knows itself best, and, by organizing space and allowing discussions, Extension can lead community action. Key Extension skills in organizing resources and facilitating community input enable citizens to guide and engage in the decision-making process.

\section{Tips for Creating Successful Community Engagement in Adaptation Planning}

A recent literature review assessed 50 studies that explored how educators and communicators have facilitated community engagement for climate-change planning (Plate et al. 
2019). The studies occurred in a variety of countries around the world and focused on vulnerabilities to climate change related to natural resources, agriculture, public health, disaster planning, and development.

The following five themes that emerged from this review provide a roadmap for agents to help improve communication and engagement in community adaptation planning. While these themes were obtained from cases based on climate adaptation, we believe they have value for facilitating community change in general:

1. Establish positive initial engagement

2. Incorporate participatory methods

3. Use tools to facilitate understanding

4. Address trust and uncertainty

\section{Maximize limited time}

These themes are relevant to multiple objectives and can provide an overall framework to guide Extension agents in their adaptation-planning endeavors. Examples from the literature are used to illustrate these themes, and case studies from Florida suggest how Extension agents can use these themes in developing programs.

\section{Establish Positive Initial Engagement}

Similar to other Extension programs or efforts, an important first step is to create positive initial engagement with the community. This step involves two key pieces: understanding your audience and strategically planning the first activities that will engage them. A successful outcome will put the next steps on a solid foundation. This is especially critical for contentious issues, where perceptions and knowledge will likely vary across stakeholders.

The method used for selecting participants with whom to engage will likely be a function of your objectives for adaptation planning. You may already have an audience in mind, or you may be designing a program that is open to the public. If community leaders are asking questions about what is possible, it might be appropriate to bring together agency staff with a range of expertise and responsibilities. If adaptation actions have been proposed, it may be useful to introduce the rationale and possibilities to the public, giving them a role to add information and prioritize actions. The studies included in the literature review typically invited a combination of participants representing different levels and types of knowledge, expertise, and leadership roles with the community (Box 4). For an issue like climate change, creating a diverse group and ensuring adequate representation from different social groups is important. Participants for beginning a planning effort were often identified through both researcher and stakeholder input, rather than being open to the general public. Many articles state, however, that for any of these plans to be implemented, the public needed to be informed and involved. You may find the strategies listed below helpful.

\section{TIPS FOR HOW TO IDENTIFY PARTICIPANTS}

- Select presenters and participants with disciplinary expertise that will help create understanding of the different factors involved (Eames et al. 2013).

- Select representatives from different sectors in the region, such as emergency response, health, agriculture, transportation, business, natural resources, etc. (Lemieux, Gray, Douglas, Nielsen, and Pearson 2014).

- Include stakeholders at the state, district, and community level as appropriate (Bhave, Mishra, and Groot 2013). Neighboring counties could offer important collaborations, for example, and state agencies might have resources to assist with this effort.

- Include both formal and informal leaders (Bardsley \& Rogers 2011; Butler et al. 2014; Matthews et al. 2008). Formal leaders are employed in a leadership capacity, but informal leaders might be critical for building community acceptance. Consider asking for participants who are faith-based leaders; high school science teachers; in civic associations such as Rotary, Junior League, and Kiwanis; and from specialty organizations such as nature centers or garden clubs.

- Focus on including "champions" as presenters, group leaders, or participants. These people are influential within the community and have pre-existing, positive relationships with many community members (Andersson, Wilk, Graham, and Warburton 2013).

- Ask an initial group of stakeholders to identify participants from their networks, with consideration for creating a diverse and balanced group (Langsdale et al. 2009, Chaudhury et al. 2016, André and Jonsson 2015) (Box 5).

After participants are identified, use introductory activities at the beginning of your first face-to-face event that will appropriately engage them in the topic of climate change adaptation. These activities should simplify the complexity of the issue and help to diffuse potentially contentious situations. Several of the studies in the literature review began by sharing risk-related, local-scale data, while also providing opportunities for group discussion and participation. 


\section{Box 4. Florida Case Study: Growing Partnerships for Resiliency}

by Holly Abeels, UF/IFAS Extension agent, Brevard County

The East Central Florida Regional Planning Council (ECFRPC) has been working for several years to build resiliency and teamwork among local and regional governments. The efforts began in 2009 when the Indian River Lagoon National Estuary Program (IRL NEP) received a Climate Ready Estuary grant to evaluate the future impacts of sea-level rise. The city of Satellite Beach partnered with the IRL NEP on this project and this led to additional work and partners in the region, including early involvement by the ECFRPC. ECFRPC received a Florida Department of Environmental Protection Grant in 2017 to work with stakeholders in Brevard and Volusia counties to develop the East Central Florida Regional Resiliency Action Plan. The goal of the plan is to "increase the ability of local and regional stakeholders to implement resiliency and climate adaptation strategies across disciplines." The plan development process included guidance from a cross-discipline steering committee comprised of 42 federal, state, regional, and local agencies, communities, and institutions including Extension. Due to Extension's previous work with the ECFRPC, Extension has been an integral partner in the creation of this plan. The steering committee helped in both organizing the stakeholder engagement workshops and in developing a recommended projection of sea-level rise for planning purposes in the east central Florida region.

The East Central Florida Regional Resiliency Action Plan incorporates a 5-year planning horizon based around the four main focus areas of the 100 Resilient Cities Program: Leadership and Strategy, Economics and Society, Infrastructure and Environment, and Health and Wellbeing. Each focus area includes a definition and a list of objectives. Action items to address the objectives were organized based upon the suggested year (1-5) of implementation or "on-going" tasks that should be conducted every year or continuously. As of June 27, 2019, the East Central Florida Regional Planning Council, the city of Cocoa, the Space Coast Transportation and Planning Office, the River to Sea Transportation and Planning Office, and Brevard County have adopted the plan.

The next step for the council was development of the ECFRPC to bring together the 8 counties and 78 cities in the region around resilience. Two committees were formed under this resolution: the council subcommittee, which drives and provides direction and considers recommendations from a steering committee, and the steering committee, which developed a structure and framework, drafted a memorandum of understanding, and provided recommendations to the council sub-committee. The steering committee was comprised of differing disciplines and expertise around the region as well as the state including Extension. The ECFRPC formalized the East Central Florida Regional Resilience Collaborative (ECFR2C) by unanimous vote on May 15, 2019. This is the 3rd collaborative in the state of Florida and the 19 th in the nation. County and city managers regionwide were encouraged to consider becoming a partner by adopting the MOU in their jurisdictions. In addition, the ECFRPC and numerous other partners, including Florida Sea Grant and UF/IFAS Extension, are now working with several municipalities in the east central Florida region on resilience and sea-level rise.

\section{Box 5. Example from the Literature: Engaging Forest Stakeholders to Increase Acceptance of Climate Change in Sweden}

A team of Swedish researchers tried a new strategy to inform forest landowners about climate change, recognizing the social barriers associated with their beliefs and the general failure of the dissemination of scientific information to this audience. They used a combination of critical discussions and reflection in a group of peers and tried to create a transformative learning opportunity to shape their perception of climate change risks, their adaptive capacity, and their trust in climate science. Twenty-seven stakeholders each participated in 3 focus group discussions (a total of 12 were offered) and then attended a final workshop. The first meeting involved discussions about climate risk and personal impressions. During the second meeting, researchers presented scientific information and facilitated discussion. At the final meeting, stakeholders ranked barriers and opportunities for adaptation.

Importantly, the research team returned to these participants for follow-up interviews 6 months later to learn whether opinions changed as a result of the program. People reported that the discussions were exciting and stimulating, and they appreciated the chance to question the experts and discuss the implications of this information. It also increased their interest in media reports of climate change. Some did not, however, express a sense of urgency about adapting to climate change, in part because the projections did not match their experience. Given the scientific uncertainty, most participants believed it was appropriate to wait and see what happens. These participants were more likely to express mistrust in the scientists. Other participants reported that the discussions increased their belief that they will see positive changes from climate change and they subsequently felt relieved. Others used the information to confirm their decision to plant different species after the recent hurricane.

Researchers summarize by saying "learning and engagement with adaptation greatly depends on how well the scientific knowledge conveyed about climate impacts and adaptive measures fits the practical needs, objectives, and aspirations of stakeholders;" that "trust in climate science is of great importance for learning and engagement with scientific knowledge;" and that how people view science and uncertainty can prevent learning (page 223).

Adapted from Vulturius and Swartling 2015

\section{TIPS FOR CREATING ENTRY ACTIVITIES}

- Encourage stakeholders to provide their own experiences in the context of the local data (Bartels et al. 2012; Bell et al. 2015; Girvetz, Gray, Tear, \& Brown 2014). This can take the form of a story, a timeline, or a map, for example.
- Start with a discussion on seasonal climatic concerns related to natural variation in weather patterns, rather than discussing climate change (Bartels et al. 2012).

- Identify local vulnerabilities with stakeholders and shared scientific predictions of future climate variability (Galicia et al. 2015). 
- Discuss local data probabilities of events such as winter wildfires, lower winter agricultural yields, dam breaks, and lack of household water (Andersson et al. 2013).

\section{Support Engagement Using a Participatory Approach}

Efforts that encourage active participation in dialogue, learning, decisions, and actions allow participants to share their knowledge and perspectives and provide ways for them to be meaningfully involved in the issue and solutions. These types of activities can lead to continued involvement, bridge the gaps among different types of stakeholders, tap into local expertise, and support social learning-where all participants can contribute and learn from one another.

\section{TIPS FOR ENGAGING PARTICIPANTS}

- Allow participants to create "influence diagrams" to depict how different climate impacts (e.g., drought, heat, fire, floods, storms, sea-level rise) affect their local ecosystems, communities, infrastructure, economy, and more. These diagrams can help participants understand multiple connections between impacts and consequences, and to identify key areas of concerns and priorities for future action (Ross et al. 2015).

- Reverse conventional roles of specialists/experts and stakeholders (Box 6), so stakeholders take the primary role in initial discussions and specialists take the role of listeners (Bartels et al. 2012).

- Divide participants into small groups by their expertise (e.g., community planners, leaders, representatives from different sectors) and then report out to larger group (Picketts et al. 2012; Frazier, Wood, and Yarnal 2010). Alternatively, you can mix groups so individuals with different expertise can promote diversity in discussions (Box 7).

- Use strategies such as community theatre, walking journeys, risk mapping, environmental monitoring, role plays, or scenario building to help participants envision and work toward the future (Tschakert et al. 2014). For example, the Sea-level Rise Adaptation Strategy Role Play Game is an engaging exercise to help participants explore adaptation strategies and practice collaboration and negotiation skills (https://planningmatanzas.org/2013/06/07/ sea-level-rise-adaptation-strategy-role-play-game/).

- Collect input from stakeholders from different educational and socio-economic backgrounds separately to ensure representation of all perspectives and to create activities that build on participants' perceptions and knowledge (Bhave et al. 2013; Christmann et al. 2015).
This can be accomplished through interviews or separate focus groups.

- Allow participants time to interact with researchers and ask questions about scientific data and graphs (Matthews et al. 2008). People often have questions about how to interpret the science and what the projections include. Finding a scientist who can explain the information clearly is important, too.

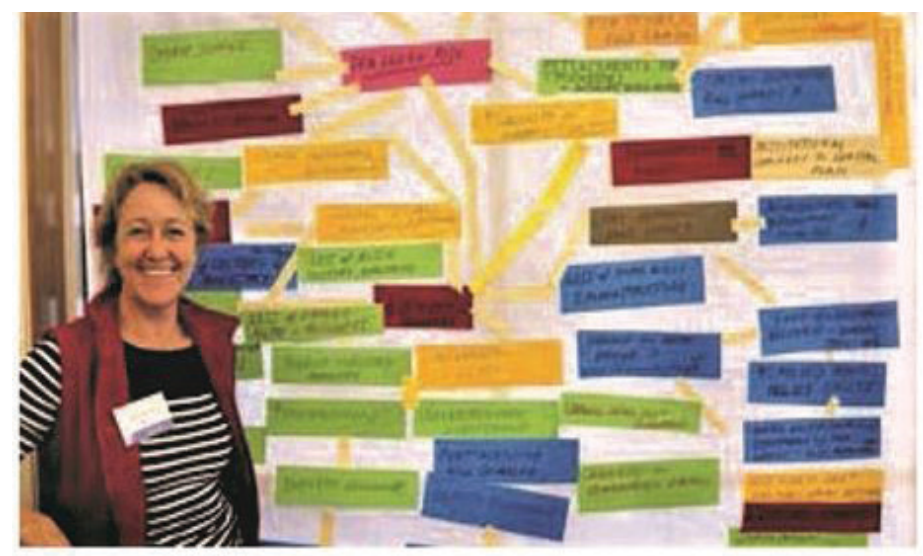

Figure 2. Influence diagram created during a climate roundtable in Southeast Queensland, Australia (Ross et al. 2012)

\section{Use Tools to Facilitate Understanding}

Tools, such as simulations, maps, or models, are an essential part of community adaptation planning for climate change, because the evidence can be hard for individuals to see and acknowledge. Tools can help participants better understand the potential impacts of climate change, better define community risks, and better assess various adaptation options. Many of the studies included in this literature found ways to incorporate participants' knowledge and experience into tools through historical timelines, sketches, and figures reporting scientific data. Numerous resources have been developed to visually explain changes in climate, and there are online tools to assist with risk assessment (see Resources section).

\section{TIPS FOR USING TOOLS TO ENHANCE UNDERSTANDING}

- Show videos and web-based maps of historic and projected change, as well as simulations to show potential climate impacts (Box 8). For example, seeing simulated coastal flooding scenarios increased participants' engagement and concern regarding sea-level rise (Bell et al. 2015; Preston et al. 2009; Dempsey and Fisher 2005; Wadey et al. 2015). Box 9 provides maps and scenarios for sea-level rise in Florida.

- Use regional maps, timelines, or other visualizations to allow participants to display their own memories of climate variability and trends, community vulnerabilities, 
resources, and activities (Furman and Bartels 2017; Dwamena et al. 2011, Andersson et al. 2013, Bartels et al. 2012). This allows participants to be a source of information, which can complement the scientific information presented.

- When explaining historic and projected climate changes to the public, create graphics or visualizations to replace busy charts of numbers (Girvetz et al. 2014; Tschaakert et al. 2014; Christmann et al. 2015). A quick Internet search will result in several online programs that can help you create infographics to help highlight key take-away messages from the data.
- Empower participants to collect their own local data by teaching them to use online vulnerability assessment tools and simulations of future impacts to help them identify risks and potential benefits of adaptation options (Licuanan et al. 2015; Mamauag et al. 2013; Preston et al. 2009; Langsdale et al. 2009).

\section{Box 6. Florida Case Study: Tristate Climate Learning Network: Row Crop Stakeholders Managing Climate Risks}

by Wendy-Lin Bartels, Research Assistant Scientist, School of Forest Resources and Conservation

In the row-crop region of the southeastern United States, where Florida, Alabama, and Georgia meet, farmers are developing strategies to manage climate risks by sharing their knowledge and experiences with one another. UF/IFAS initiated the "tristate climate learning network" in 2009, with strong support from Extension professionals from two other Land Grant Institutions (University of Georgia and Auburn University). This cross-state collaborative partnership demonstrates the potential for involving farmers as active and critical partners in knowledge generation for climate adaptation (Prokopy et al. 2017).

For 10 years, peanut, cotton, and corn growers have been coming together biannually to exchange ideas, consider adaptive management practices and identify climate-related information gaps. Each year before planting and harvesting (in February and August), participants gather to discuss the potential impacts of seasonal variability on their cropping systems. Workshops include on-farm experiential components, such as assessing drip irrigation options, cover crop varieties, pond water harvesting techniques, or drought-tolerant alternate crops, like sesame. Agendas also situate discussions in classroom-style interactions and presentations. For example, adaptive planning options are guided by forecasts from the Florida State Climatologist and examinations of AgroClimate, a sophisticated online decision support system (Bartels et al. 2012).

During workshops, the facilitator encourages full participation and uses tools that prevent one knowledge system or worldview from dominating discussions. As a result, scientists who participate in the tristate network are learning from and with agricultural stakeholders. In this way, the tristate network offers opportunities to reduce the gap between research and practice, making climate science more relevant to agricultural decision makers. The continued nature of engagement (20 workshops) demonstrates how Extension agents can create a platform for farmers and scientists to learn from each other over time and adapt to new weather patterns (Furman, Bartels, and Bolson 2018).

\section{Box 7. Example from the Literature: One Day Workshop Informs Land-use Planning}

Many land-use planners in Florida's coastal communities work to balance continued growth and prosperity with sea-level rise and the threat of hurricanes. Organizers developed a one-day workshop for planners in Sarasota County to help them reflect on the overlapping problems generated by significant growth and storm surge threats. Thirty-three representatives from five groups were invited: local government, land-use planning, business community, emergency management, and environmental interests. The agenda included participatory mapping sessions and expert-group discussions to capture the unique perspectives from each of the sectors. Two hazard scenarios were introduced with a GIS analysis of the current storm surge hazard zones with category 1-5 hurricanes and future zones with sea-level rise of $30,60,90$, and $120 \mathrm{~cm}$.

The first group task was to "determine if and how they would reallocate land use based on" their knowledge and the projections of land use in 2050 of storm-surge hazard zones for a range of hurricane-strength storms (page 510). After discussing all five maps, the group began the second task, which involved the same projection for land use with 4 projections of sea-level rise with a category 3 hurricane. Because most of the development is already on the coast, stronger storms did not alter the hazard.

The emergency response group noted that most of the county's infrastructure was in the current and future storm surge zones and could all fail in the event of a hurricane. They suggested relocating facilities out of the hazard zone, but perceived that rebuilding facilities before the end of their life span would be difficult without strong public support. The second scenario, with climate change, added a sense of urgency to consider adaptation strategies. The county's urban service boundary significantly constrains future growth in less vulnerable areas, which suggests it would be useful to consider changing the comprehensive plan and land-use codes. This stakeholder workshop enabled local experts to learn, consider future hazards, and reconceptualize land-use plans in Sarasota County. They reported that implementing adaptation plans would require significant education and engagement of the public.

Adapted from Frazier, Wood, and Yarnal 2010 


\section{Box 8. Example from the Literature: Using Visualizations as a Tool in Participatory Coastal Management}

In the United Kingdom, a focused effort to help coastal managers communicate with the public has explored visualization techniques about coastal management strategies for sea-level rise. Two selected study sites along the Norfolk coast were already experiencing issues related to sea-level rise, and managers were exploring different management options to address concerns. A series of images and animations showing the coastlines before and after different management options was created using GIS and other mapping software. Interviews were then conducted with coastal managers to synthesize the advantages and disadvantages of using computer visualizations as a public education tool.

Managers felt that visualizations could be an effective tool for communicating with stakeholders and the public, particularly when management options have been identified and public input is needed regarding the preferred solution. Managers felt that seeing images of how management strategies can influence the landscape in different ways could focus discussions and clarify perceptions of potential future conditions. The visualizations were also perceived to be easier to understand than traditional maps and an improvement over other types of images, such as drawings and photos. The managers acknowledged that it would be difficult to have a truly participatory process where the public was involved in creating the management options being discussed because that would necessitate a high level of scientific and engineering expertise. That said, visualizations can be a "valuable tool to aid the communication and discussion of future costal management interventions, particularly at the site level." The authors suggest future studies should test the visualizations in participatory processes with the public and stakeholder groups.

Adapted from Jude 2008

\section{Box 9. Sea-level Rise and Coastal Flooding Visualization Tools}

The following online tools help to visualize impacts from sea-level rise and coastal flooding:

\section{Gulf TREE:}

Need help finding the right tool? Gulf TREE is an interactive decision-support tree to help users find the right climate tool for their needs. http://www.gulftree.org/

\section{NOAA Coastal Flood Exposure Mapper:}

Online tool for visualizing coastal hazard risks and social, ecosystem, and infrastructure vulnerabilities. Available for coastal areas of the United States.

https://coast.noaa.gov/digitalcoast/tools/flood-exposure.html

\section{NOAA Sea-level Rise Viewer:}

Online tool for visualizing sea-level rise up to $10 \mathrm{ft}$ above average high tides. Available for coastal areas of the United States.

https://coast.noaa.gov/digitalcoast/tools/slr.html

\section{Sea-level Scenario Sketch Planning Tool:}

Online tool showing local SLR projections and impacted transportation facilities for the state of Florida.

https://sls.geoplan.ufl.edu/

Climate Central's Surging Seas Risk Finder:

Maps, tools, and analyses that depict coastal flood risk for multiple states: https://riskfinder.climatecentral.org

\section{Address Trust and Uncertainty}

As you likely know from previous Extension efforts in your community, lack of trust and uncertainty are significant barriers to addressing complex issues such as climate change. Successful programs include multiple strategies for building trust and addressing uncertainty, often starting with the initial engagement and visualization of data. Several studies included in the literature review report that using local data, relevant contexts, and clear language were most helpful in developing trust with participants (Box 10). The following tips can be embedded in strategies that achieve the other goals as well.

\section{TIPS TO BUILD TRUST AND REDUCE UNCERTAINTY}

- Ask organizations and institutions that are perceived as trustworthy and credible to be involved in hosting your events (Dempsey and Fisher 2005). While trust in national organizations may be low, local scientists tend to be perceived as more trustworthy.

- Provide sources of data when possible, in addition to summaries or charts, so that participants can investigate and explore the data at their convenience and acknowledge the levels of uncertainty that exist (Matthews et al. 2008). Teachers and forest landowners have specifically stated that seeing citations and hearing about research studies increased their trust in the data as well as the speaker (Monroe, Oxarart, and Walkingstick 2019). 


\section{Box 10. Example from the Literature: Building Trust through Group Model Building}

Climate change scenarios and impacts are often communicated to decision makers and stakeholders by sharing data generated through various models. However, without an understanding of the process used to build and verify the model, the results may not be trusted or used. Group model building is a strategy that can overcome this challenge because it allows participants to better understand the model's limitations, assumptions, and levels of uncertainty.

To help a community in British Columbia plan for water management in future climate conditions and to explore group-model-building processes, a team of researchers conducted a series of five stakeholder workshops in Okanagan Basin-one of the most arid regions in Canada. The workshops had three objectives: to create a shared learning experience, to develop a customized exploration tool, and to foster trust in the model among the participants.

The research team had previously worked in the community and had already established trusting relationships that provided a foundation for the group-model-building process. The team invited key individuals and representatives to participate, making sure that participants represented all major interests and agencies in the area. The intent was for these individuals to participate in all five workshops over the course of one year; however, not all participants were able to attend each workshop and participant turnover was higher than expected.

At the workshops, the participants were engaged in numerous activities and discussions to help learn about, design, and test the model. They provided input and advice that the modelers then used to construct the model in between meetings. For example, the participants sketched the first version of the model on big paper, reviewed and tested early versions, and validated results with personal experience.

The workshops were designed around the principle that "if participants understand and trust the model, they will be inclined to more seriously consider the results and to incorporate them into their own work." Indeed, the participants' trust in the model increased as they learned more, and the model became more refined. However, the "high turnover rate in participation limited the sense of ownership in the model by the completion of the final session."

The team suggests that better communication regarding schedules could have improved attendance, more frequent workshops could have kept participants better engaged in the model development process, and providing model documentation and ground rules before or at the workshops could have helped increase familiarity and feelings of ownership.

Adapted from Langsdale et al. 2009

- Determine the appropriate level of information to provide to your audience-avoid overwhelming people with technical terms and abstract concepts, but don't oversimplify either (Stott and Huq 2013). This balance can be achieved through a presentation that invites and encourages interaction, which is more likely if the initial engagement creates an atmosphere of participation and acceptance. Make sure your facilitators and speakers are personable, comfortable with this type of programming, and trusted members of the community.

- When considering the actions that your community might undertake, identify and prioritize "no-regret" actions that would be useful in addressing climate change impacts but also in improving quality of life in the context of any future climate scenarios (Butler et al. 2014; Luque, Edwards, and Lalande 2013; and Cross et al. 2013). This may reduce the need to agree upon climate projections because these actions are beneficial for several reasons.

- One aspect of successful deliberative discussions is to make sure that all perspectives and opinions are represented in the framing of options-including their advantages and disadvantages. Use various future scenarios so participants can consider contingency plans in the face of significant variance (Cross et al. 2013). It may be helpful to enlist the support of an advisory group with both conservative and liberal perspectives so that the discussion is framed to appeal to all opinions.

\section{Maximize Limited Time}

Getting participants to commit a substantial amount of time can be a challenge for Extension programs. Communities are not likely to develop an adaptation plan overnight. Consider framing a long-term process that involves different audiences for different purposes and that incorporates specific engaging programs for each need. Use partner agencies and community leaders to develop this strategy and think about when experts should be involved, when the public should be informed, and when public discussions and priorities will be helpful. While the entire process might take six months or more (Box 11), an individual may be involved for a two-hour program once or twice. This means it will be important to keep records of the outcomes of each meeting and share them with future participants. You can also plan shorter programs, such as a one-day workshop, to begin creating an adaptation plan with a group of stakeholders (Box 12). Authors of the reviewed studies suggest that having strategies to maximize your participants' limited availability is an important determinant of success.

\section{TIPS FOR MAXIMIZING LIMITED TIME}

- Establish clear, agreed-upon goals and objectives to keep discussions on track and increase stakeholder satisfaction with the outcomes (Andersson et al. 2013; Byers et al. 2014; Langsdale et al. 2009). 


\section{Box 11. Florida Case Study: Pinellas County Extension Bridges Climate, Science, Citizens, and Policy}

As a result of climate change and sea-level rise, Pinellas County government is considering adjustments to plan for emerging threats to infrastructure, public health, and natural resources. The lack of coordinated state and federal guidance for climate adaptation prompted local entities to initiate their own planning efforts. Yet communities frequently lack staff and fiscal and scientific resources to identify risks and plan for adaptation. To address this challenge, the Extension agent established the Tampa Bay Climate Science Advisory Panel (CSAP) to provide scientific support to local governments planning for a changing climate. Specifically, she facilitated a year-long process that engaged scientists in a literature review, expert speaker presentations, and discussion that led to the development of "Recommended Projection of Sea-Level Rise in the Tampa Bay Region." Since the adoption of the recommended projection for Tampa Bay, local governments are increasing their awareness of climate change and sea-level rise issues, conducting vulnerability assessments, and incorporating appropriate coastaladaptation and risk-reduction strategies into their planning processes.

Although this process was challenging, these activities can begin even without funding. Local experts are available and just need to be asked to assist. Transparency in the process is critical to establishing trust. Working regionally can be ideal for creating local solutions and focusing on the best available science. Once a framework is established, it can be updated with new insights. Establishing a process that engages all stakeholders is not only productive, it is rewarding.

\section{Box 12. Example from the Literature: Designing a Workshop to Build Local Capacity for Climate Change Adaptation Planning in British Columbia}

In the city of Prince George in northern Canada, a team of researchers, city staff, and others organized a community-based workshop to help the city begin planning adaptation strategies for climate change. The team began by inviting city staff to represent different sections, including planning, environmental, utility, and transportation departments. After inviting the initial group, they opened the workshop to allow other interested parties and organizations to participate, for a total of 34 workshop attendees. While the participants reported being interested in participating, they also expressed concerns about committing more than one day of time to this project. The organizers addressed this concern by creatively designing the workshop agenda to efficiently meet their objectives within a single day. The 6-part agenda (see table 2) allowed the group to successfully understand current and projected changes, to identify and prioritize risks, and to create a vision for an adaptation strategy.

This model can be modified and applied in other communities where the group has limited ability to commit to a long-term planning process. However, it is important to consider the authors' note that the city of Prince George had previously worked on adaptation and been exposed to climate impacts. This allowed the team to have a short introduction to the topic, helped to focus discussions, and led to local interest that motivated participation by senior staff and stakeholders. The authors recommend that "Communities with less capacity and experience will have to dedicate more time to background information, may require more guidance and facilitation throughout the day, and may need more than a single day to achieve the desired objectives."

Adapted from Picketts et al. 2012

- Create personal relationships and multiple opportunities for involvement to increase participation rates in future activities (Andersson et al. 2013).

- Avoid busy times of the year for your stakeholders, for example planting or harvesting season if working with farmers (Andersson et al. 2013).

- Share documents or have a webinar before the event to introduce the topic and provide the necessary background information (Cross et al. 2013; Picketts et al. 2012).

- Have participants complete pre-workshop surveys to focus the adaptive-planning exercises on meeting their needs, expectations, and previous experiences (Cross et al. 2013; Cone et al. 2013).

\section{Abstract}

The Florida Cooperative Extension Service is a valuable link between research and the public. We partner with other state agencies and serve local municipalities with information and programs to engage people in planning for change. Like economic development or life skills for youth, climate change adaptation programs can address many different stakeholders and catalyze opportunities across a region.

The Florida Cooperative Extension Service's CIVIC Program offers strategies for engaging residents in meaningful discussions that can help municipalities select options for further research or provide data about what informed members of the public consider important.

This guide summarizes several key strategies that should be considered as agents work with partners to plan programs on controversial issues such as climate change and sea-level rise:

1. Establish positive initial engagement by carefully identifying who should attend and establishing a welcoming atmosphere.

2. Incorporate participatory methods in the workshop or meeting to engage the participants.

3. Use tools such as websites, models, and maps to facilitate understanding. 
4. Address trust and uncertainty by thinking about your partners, hot-button issues that could offend participants, and which tools can help demonstrate vulnerability and risk.

5. Maximize limited time. No one has time to waste, and this issue is likely only one among many things participants care about.

Despite different perceptions of the causes of climate change, there is increasing support in communities for exploring effective and reasonable strategies for reducing risk and enhancing community well-being. Many different resources are available to assist with this work through the University of Florida (UF), Florida Agricultural and Mechanical University (FAMU), and other universities, Florida agencies, and regional planning units. Extension agents have the skills and mandate to become key players in this work.

\section{Resources}

\section{Climate Change and Impacts}

- National Climate Assessment 2018: Summary of Findings includes impacts to different sectors and areas, includes a chapter on southeastern US. summary. https://nca2018. globalchange.gov

- Global Climate Change, NASA: Provides information on the evidence, causes, effects, and uncertainties of climate change. https://climate.nasa.gov/

- NOAA, Climate.gov: This website provides science and information about climate, with a goal of helping people make decisions on how to manage the climate-related risks and opportunities they face. https://www.climate. gov/

- Climate Resilience Evaluation and Awareness Tool (CREAT) Climate Scenarios Projection Map: Interactive EPA map that allows the user to see expected changes in temperature, sea level, precipitation, and more for specific geographic locations. https://epa.maps.arcgis.com/apps/ MapSeries/index.html?appid=3805293158d54846a29f750 d63c6890e

- Future Urban Climates: This University of Maryland web app allows you to imagine what a selected city will feel like in 2080 under different emission scenarios by comparing the city to another location's current climate conditions. https://www.umces.edu/futureurbanclimates

- PINEMAP Decision Support System: This regional website enables users to select specific locations in the southeast and learn how precipitation and temperature are likely to change over time. http://pinemapdss.org

- Florida Climate Institute: The FCI provides resources, events, and a network of national and international research and public organizations, scientists, and individuals that may be helpful as Extension agents begin climate conversations in communities. https://floridaclimateinstitute.org/

- Florida Climate Center and State Climatologist: The Florida Climate Center provides information on several climate-related topics, data and projections, and other services. https://climatecenter.fsu.edu

- Florida State University, Center for Ocean-Atmospheric Prediction Studies (COAPS): COAPS performs interdisciplinary research in ocean-atmosphere-land-ice interactions to increase understanding of the physical, social and economic consequences of climate variability. https://www.coaps.fsu.edu/

- Florida International University, Sea Level Solutions Center: The Sea Level Solutions Center works with experts worldwide to develop sea level responses. https:// slsc.fiu.edu/

\section{EDIS DOCUMENTS}

- Science Support for Climate Change Adaptation in South Florida. https://edis.ifas.ufl.edu/uw331

- Economic Impacts of Climate Change on Florida: Estimates from Two Studies. https://edis.ifas.ufl.edu/fe787

- The Potential Effects of Sea-Level Rise on Florida's Coastal Ecosystems. http://edis.ifas.ufl.edu/sg131

\section{Adaptation Strategies and Tools}

- Forest Adaptation Workbook: A helpful workbook for Extension faculty working with forest landowners and managers. The book walks through identifying goals, location-specific impacts and vulnerabilities, challenges and opportunities, and specific actions. https://adaptationworkbook.org/

- EPA List of Adaptation Planning Tools: A set of adaptation resources and tools. https://www.epa.gov/arc- $\mathrm{x} /$ tools-climate-change-adaptation

- Climate Change Adaptation Workshops: A Planning Guide for Local Government Staff: This guidebook is focused on workshops and includes step-by-step instructions and tips. Has public health examples. http://www. acgov.org/sustain/what/climate/adaptation.htm

- Guide to Climate Change Adaptation in Cities https:// openknowledge.worldbank.org/handle/10986/27396 
- Florida Resilient Coastlines Program-Resources, tools, and grants:https://floridadep.gov/ $\mathrm{rcp} /$ florida-resilient-coastlines-program/content/ resilience-resources

- Adaptation Planning Guidebook:https://floridadep.gov/ rcp/florida-resilient-coastlines-program/documents/ adaptation-planning-guidebook

- Florida Department of Economic Opportunity-Community Resiliency Initiative: Resources and tools:http:// www.floridajobs.org/community-planning-and-development/programs/community-planning-table-of-contents/ adaptation-planning

\section{EDIS DOCUMENTS}

- Risk Perception and Needs: Defining Extension's Climate Change Adaptation Role https://edis.ifas.ufl.edu/fr403

- Climate Change Adaptation: New Perspectives for Natural Resource Management and Conservation https:// edis.ifas.ufl.edu/uw363

- Planning for Climate Change in South Florida: Climate Envelope Modeling for Threatened and Endangered Species http://edis.ifas.ufl.edu/uw327

- Adaptation Approaches to Sea-Level Rise in Florida http://edis.ifas.ufl.edu/wc171

\section{Communication and Facilitation}

- National Issues Forums Institute: Find background on deliberation, issue guides, and moderator resources. https://www.nifi.org/

- NAAEE, Environmental Issues Forum, Climate Choices: A set of resources for those wanting to use the Climate Choices Issue Guide. https://naaee.org/eepro/resources/ climate-choices-how-should-we-meet

- Climate Choices Issue Guide PDF: https://www.nifi.org/ en/catalog/product/climate-choices-how-should-wemeet-challenges-warming-planet-issue-guide

- Global Warming's Six Americas, Yale Program on Climate Change Communication https://climatecommunication. yale.edu/about/projects/global-warmings-six-americas/

\section{EDIS DOCUMENTS}

- Challenges in Communicating Climate Change to Extension Audience http://edis.ifas.ufl.edu/fr392

- Strategies for Communicating Climate Change to Extension Audiences https://edis.ifas.ufl.edu/fr402

- Speaking with Policymakers About Current Issues http:// edis.ifas.ufl.edu/wc152
- Effective Practice for Building Cross Sector Partnerships http://edis.ifas.ufl.edu/wc271

- How Problems Gain Importance and Become Contentious Issues through Agenda Setting http://edis.ifas.ufl.edu/ wc177

\section{References}

Andersson, L., J. Wilk, L. P. Graham, and M. Warburton. 2013. "Design and test of a model-assisted participatory process for the formulation of a local climate adaptation plan." Climate \& Development 5(3): 217-228. https://doi.or $\mathrm{g} / 10.1080 / 17565529.2013 .812955$

André, K., and C. A. Jonsson. 2015. "Science-practice interactions linked to climate adaptation in two contexts: municipal planning and forestry in Sweden." Journal of Environmental Planning \& Management 58(2): 297-314. https://doi.org/10.1080/09640568.2013.854717

Bardsley, D. K., and S. M. Sweeney. 2010. "Guiding climate change adaptation within vulnerable natural resource management systems." Environmental Management 45(5): 1127-1141. https://doi.org/10.1007/s00267-010-9487-1

Bartels, W., C. A. Furman, D. C. Diehl, F. S. Royce, D. R. Dourte, B. Ortiz, D. F. Zierden, T. A. Irani, C. W. Fraisse, and J.W. Jones. 2012. "Warming up to climate change: A participatory approach to engaging with agricultural stakeholders in the Southeast US." Journal of Regional Environmental Change 13: 45-55. DOI 10.1007/s10113-012-0371-9

Bell, E. J., P. Turner, H. Meinke, and N. J. Holbrook. 2015. "Developing rural community health risk assessments for climate change: A Tasmanian pilot study." Rural \& Remote Health 15(3): 1-15. Retrieved from http:// www.rrh.org.au/ journal/article/3174

Bhave, A., A. Mishra, \& A. Groot. 2013. "Sub-basin scale characterization of climate change vulnerability, impacts and adaptation in an Indian River basin." Regional Environmental Change 13(5): 1087-1098. https://doi.org/10.1007/ s10113-013-0416-8

Bormann, H., F. Ahlhorn, and T. Klenke. 2012. "Adaptation of water management to regional climate change in a coastal region-Hydrological change vs. community perception and strategies." Journal of Hydrology 454-455, 64-75. https://doi.org/10.1016/j.jhydrol.2012.05.063

Butler, J. R. A., W. Suadnya, K. Puspadi, Y. Sutaryono, R. M. Wise, T. D. Skewes, ... A. Ash. 2014. "Framing the application of adaptation pathways for rural livelihoods and 
global change in eastern Indonesian islands." Global Environmental Change Part A: Human \& Policy Dimensions 28: 368-382. https://doi.org/10.1016/j.gloenvcha.2013.12.004

Byers, A. C., D. C. McKinney, S. Thakali, and M. SomosValenzuela. 2014. "Promoting science-based, communitydriven approaches to climate change adaptation in glaciated mountain ranges: HiMAP." Geography 99(3): 143-152.

Chaudhury, A., A. Helfgott, T. Thornton, and C. Sova. 2016. "Participatory adaptation planning and costing. Applications in agricultural adaptation in western Kenya." Mitigation \& Adaptation Strategies for Global Change 21(3): 301-322. https://doi.org/10.1007/s11027-014-9600-5

Christmann, S., A. Aw-Hassan, T. Rajabov, and A. Rabbimov. 2015. "Collective action for common rangelands improvement: A climate change adaptation strategy in Uzbekistan." Society \& Natural Resources 28(3): 280-295. https://doi.org/10.1080/08941920.2014.933927

Clayton, S., P. Devine-Wright, P. C. Stern, L. Whitmarsh, A. Carrico, L. Steg, J. Swim, and M. Bonnes. 2015. "Psychological research and global climate change." Nature climate change 5(7): 640-646.

Cone, J., S. Rowe, J. Borberg, E. Stancioff, B. Doore, and K. Grant. 2013. "Reframing engagement methods for climate change adaptation." Coastal Management 41(4): 345-360. https://doi.org/10.1080/08920753.2013.803926

Cross, M. S., P. D. McCarthy, G. Garfin, D. Gori, and C. A. F. Enquist. 2013. "Accelerating adaptation of natural resource management to address climate change." Conservation Biology 27(1): 4-13. https://doi. org/10.1111/j.1523-1739.2012.01954.x

Dempsey, R., and A. Fisher. 2005. "Consortium for Atlantic Regional Assessment: Information tools for community adaptation to changes in climate or land use." Risk Analysis: An International Journal 25(6): 1495-1509. https://doi. org/10.1111/j.1539-6924.2005.00695.x

Dourte, D. R., W. Bartels, and C.W. Fraisse. 2015. "Exploring changes in rainfall intensity and seasonal variability in the Southeastern U.S.: Stakeholder engagement, observations, and adaptation." Climate Risk Management Volume 7, 2015, Pages 11-19

Dwamena, E., R. Banaynal, and F. Kemausuor. 2011. "Participatory three dimensional model mapping (P3DM): Expanding rural horizons and decision making for food security planning, climate change adaptation and flood risk reduction in Ghana." Research Journal of Agricultural Science 43(4): 186-195.

Eames, M., T. Dixon, T. May, and M. Hunt. 2013. "City futures: Exploring urban retrofit and sustainable transitions." Building Research \& Information 41(5): 504-516. https://doi.org/10.1080/09613218.2013.805063

Frazier, T. G., N. Wood, and B. Yarnal. 2010. "Stakeholder perspectives on land-use strategies for adapting to climatechange-enhanced coastal hazards: Sarasota, Florida." Applied Geography 30(4): 506-517. https://doi.org/10.1016/j. apgeog.2010.05.007

Frazier, T. G., N. Wood, and B. Yarnal. 2010. "Stakeholder perspectives on land-use strategies for adapting to climatechange-enhanced coastal hazards: Sarasota, Florida." Applied Geography 30(4): 506-517. https://doi.org/10.1016/j. apgeog.2010.05.007

Furman, C. A., and W. Bartels. 2017. "Climate histories in black and white: Contextualizing climate services through anthropology" Practicing Anthropology Vol 31. No. 1 Winter 2017

Furman, C. A., W. Bartels, and J. Bolson. 2018. "Participation, process, and partnerships: Enhancing climate change adaptation through meaningful long-term stakeholder engagement." Anthropology in Action. Vol. 25. Issue 3. Winter 2018.

Füssel, H. M. 2007. "Adaptation planning for climate change: concepts, assessment approaches, and key lessons." Sustainability Science 2(2):265-275. DOI 10.1007/ s11625-007-0032-y

Galicia, L., V. Magaña, and L. Gómez-Mendoza. 2015. "Climate change impacts and adaptation strategies in temperate forests in Central Mexico: A participatory approach." Mitigation \& Adaptation Strategies for Global Change 20(1): 21-42. https://doi.org/10.1007/s11027-013-9477-8

Girvetz, E., E. Gray, T. Tear, and M. Brown. 2014. "Bridging climate science to adaptation action in data sparse Tanzania." Environmental Conservation 41(2): 229-238. https:// doi.org/10.1017/S0376892914000010

IPCC. 2014. "Climate change 2014: Impacts, adaptation, and vulnerability. Part B: Regional aspects. Contribution of Working Group II to the fifth assessment report of the Intergovernmental Panel on Climate Change." Geneva, 
Switzerland: IPCC. Retrieved from http://www.ipcc.ch/ report/ar5/wg2/

Jude, S. 2008. "Investigating the potential role of visualization techniques in participatory coastal management." Coastal Management 36(4): 331-349. https://doi. org/10.1080/08920750802266346

Kaplan, S., and R. Kaplan. 2009. “Creating a larger role for environmental psychology: The Reasonable Person Model as an integrative framework." Journal of Environmental Psychology 29: 329-339.

Langsdale, S. M., A. Beall, J. Carmichael, S. J. Cohen, C. B. Forster, and T. Neale. 2009. "Exploring the implications of climate change on water resources through participatory modeling: Case study of the Okanagan Basin, British Columbia." Journal of Water Resources Planning \& Management 135(5): 373-381. https://doi.org/10.1061/ (ASCE)0733-9496(2009)135:5(373)

Lemieux, C. J., P. A. Gray, A. G. Douglas, G. Nielsen, and D. Pearson. 2014. "From science to policy: The making of a watershed-scale climate change adaptation strategy." Environmental Science \& Policy 42: 123-137. https://doi. org/10.1016/j.envsci.2014.06.004

Licuanan, W. Y., M. S. Samson, S. S. Mamauag, L. T. David, R. B. Rosario, M. C. C. Quibilan, ... P. M. Aliño. 2015. "I-C-SEA Change: A participatory tool for rapid assessment of vulnerability of tropical coastal communities to climate change impacts." AMBIO - A Journal of the Human Environment 44(8): 718-736. https://doi.org/10.1007/ s13280-015-0652-x

Luque, A., G. A. S. Edwards, and C. Lalande. 2013. "The local governance of climate change: New tools to respond to old limitations in Esmeraldas, Ecuador." Local Environment 18(6): 738-751. https://doi.org/10.1080/13549839.2012.71 6414

Mamauag, S. S. 2013. "A framework for vulnerability assessment of coastal fisheries ecosystems to climate change - Tool for understanding resilience of fisheries [VATURF]." Fisheries Research 147(none): 381-393. https://doi. org/10.1016/j.fishres.2013.07.007

Martin, T. A., D. C. Adams, M. J. Cohen, R. M. Crandall, C. A. Gonzalez-Benecke, J. A. Smith, and J. G. Vogel. 2017. "Managing Florida's plantation forests in a changing climate." In: Florida's Climate: Changes, Variations, \& Impacts, edited by E. P. Chassignet, J. W. Jones, V. Misra, and J. Obeysekera, Gainesville, Florida: Florida Climate Institute. pp. 269-295.

Matthews, K. B., M. Rivington, K. Buchan, D. Miller, and G. Bellocchi. 2008. "Characterising the agro-meteorological implications of climate change scenarios for land management stakeholders." Climate Research 37(1): 59-75. https:// doi.org/10.3354/cr00751

McNeeley, S. M., and H. Lazrus. 2014. " The cultural theory of risk for climate change adaptation." Weather, Climate and Society 6: 506-519.

Meyer, R., and H. Kunreuther. 2017. The Ostrich Paradox: Why we underprepare for disasters. Philadelphia, PA: Wharton Digital Press.

Monroe, M. C., L. McDonell, A. Oxarart, and R. Plate. 2009. "Using community forums to enhance public engagement in environmental issues." Journal of Education for Sustainable Development. 3(2): 171-182.

Monroe, M.C., A. Oxarart, and T. Walkingstick. 2019. "Talking about climate change: How to enhance trust with forestry audiences." Applied Environmental Education \& Communication 18(1): 43-52, DOI: 10.1080/1533015X.2018.1431164.

Moser, S. C., and J. A. Ekstrom. 2010. "A framework to diagnose barriers to climate change adaptation." Proceedings of the National Academy of Sciences 107(51): 22026-22031. https://doi.org/10.1073/pnas.1007887107

Park, S., M. Howden, and S. Crimp. 2012. "Informing regional level policy development and actions for increased adaptive capacity in rural livelihoods." Environmental Science \& Policy 15(1): 23-37. https://doi.org/10.1016/j. envsci.2011.09.004

Picketts, I. M., A. T. Werner, T. Q. Murdock, J. Curry, S. J. Déry, and D. Dyer. 2012. "Planning for climate change adaptation: Lessons learned from a community-based workshop." Environmental Science \& Policy 17: 82-93. https://doi.org/10.1016/j.envsci.2011.12.011

Piya, L., K. Maharjan, and N. Joshi. 2013. "Determinants of adaptation practices to climate change by Chepang households in the rural Mid-Hills of Nepal." Regional Environmental Change 13(2): 437-447. https://doi.org/10.1007/ s10113-012-0359-5 
Plate, R. R., M. C. Monroe, W. Friedrichsen, A. Bowers, and W. Chaves Didier. (In review). "Recommendations for Engaging Communities in Early Stages of Climate Change Adaptation." Journal of Human Sciences and Extension.

Preston, B. L., C. Brooke, T. G. Measham, T. F. Smith, and R. Gorddard. 2009. "Igniting change in local government: Lessons learned from a bushfire vulnerability assessment." Mitigation \& Adaptation Strategies for Global Change 14(3): 251-283. https://doi.org/10.1007/s11027-008-9163-4

Prokopy, L. S., W. Bartels, G. Burniske, and R. Power. 2017. "Agricultural Extension and Climate Change Communication" Oxford Research Encyclopedia of Climate Science. Oct 2017. http://climatescience.oxfordre.com/ view/10.1093/acrefore/9780190228620.001.0001/ acrefore-9780190228620-e-429?rskey $=8 \mathrm{~s} 4 \mathrm{j}$ VX\&result $=1$

Rafferty, A. E., and M. A. Griffin. 2006. "Perceptions of organizational change: a stress and coping perspective." Journal of Applied Psychology 91 (5): 1154-1162. http:// www.jwalkonline.org/docs/Grad\%20Classes/Fall\%2007/ Org\%20Psy/Cases/satisfaction/articles/perceptions\%20 of\%20organizational\%20change.pdf

Reser, J. P., and J. K. Swim. 2011. "Adapting to and coping with the threat and impact of climate change." American Psychologist 66 (4): 277-289. https://doi.org/10.1037/ a0023412

Ross, H., S. Shaw, J. Schoeman, S. Chapman, N. Cliffe, D. Rissik, V. Hounsell, J. Udy, and N. Nghia Trinh. 2012. Climate Roundtables Southeast Queensland: short report. Global Change Institute, The University of Queensland.

Ross, H., S. Shaw, J. Schoeman, D. Rissik, N. Cliffe, S. Chapman, ... N. Trinh. 2015. "A participatory systems approach to understanding climate adaptation needs." Climatic Change 129(1/2): 27-42. https://doi.org/10.1007/ s10584-014-1318-6

Sarkis, S. A. 2017. "Ten Ways to Cope with Big Changes." Psychology Today. https://www.psychologytoday.com/us/ blog/here-there-and-everywhere/201701/10-ways-copebig-changes

Stott, C., and S. Huq. 2014. "Knowledge flows in climate change adaptation: Exploring friction between scales." Climate \& Development 6(4): 382-387. https://doi.org/10.10 $80 / 17565529.2014 .951014$
Tschakert, P., K. Dietrich, K. Tamminga, E. Prins, J. Shaffer, E. Liwenga, and A. Asiedu. 2014. "Learning and envisioning under climatic uncertainty: An African experience." Environment \& Planning A 46(5): 1049-1068. https://doi. org/10.1068/a46257

Vulturius, G., and Å. G Swartling. 2015. "Overcoming social barriers to learning and engagement with climate change adaptation: Experiences with Swedish forestry stakeholders." Scandinavian Journal of Forest Research 30(3): 217-225. https://doi.org/10.1080/02827581.2014.10 02218

Wadey, M. P., S. N. Cope, R. J. Nicholls, K. McHugh, G. Grewcock, and T. Mason. 2015. "Coastal flood analysis and visualisation for a small town." Ocean \& Coastal Management 116: 237-247. https://doi.org/10.1016/j. ocecoaman.2015.07.028

Walsh, J., and D. Webbles. 2014. "Changes in storms. Our changing climate." National Climate Assessment [NSA] https://nca2014.globalchange.gov/report/ our-changing-climate/changes-storms.

Weick, Karl E. 1984. "Small Wins: Redefining the scale of social problems." American Psychologist 39 (1): 40-49. 


\begin{tabular}{|c|c|c|c|}
\hline \multicolumn{4}{|c|}{ Strategies for Understanding Phase } \\
\hline If Your Objective Is To... & During Planning, You Need To... & Consider These Questions & Potential Actions with Community \\
\hline $\begin{array}{l}\text { Increase awareness or } \\
\text { knowledge of actual and } \\
\text { expected climate changes } \\
\text { in community }\end{array}$ & $\begin{array}{l}\text { Consider who should attend this } \\
\text { meeting, how much time you will } \\
\text { have, and how much they already } \\
\text { know. } \\
\text { Identify local sources of help, } \\
\text { including agency staff who can } \\
\text { provide resources or be guest } \\
\text { speakers. } \\
\text { Review what your speakers are } \\
\text { planning to offer in advance, and } \\
\text { help experts make the information } \\
\text { interesting and relevant. } \\
\text { Include time in your agenda to hear } \\
\text { from participants. }\end{array}$ & $\begin{array}{l}\text { What has already been done to } \\
\text { communicate this issue? } \\
\text { What gaps exist in community } \\
\text { understanding about this issue? } \\
\text { Is your audience already } \\
\text { determined? Can you conduct a } \\
\text { needs assessment? } \\
\text { Can you attract a specific audience? } \\
\text { Can you ask them to register } \\
\text { in advance and complete a } \\
\text { questionnaire? } \\
\text { Is this event open to the public? } \\
\text { What assumptions can you make } \\
\text { about what they know and care } \\
\text { about? } \\
\text { How big is "your community?" } \\
\text { If this is a county program, is } \\
\text { there adequate geographic } \\
\text { representation as well as context } \\
\text { expertise? }\end{array}$ & $\begin{array}{l}\text { Listen to participant experiences } \\
\text { with climate variability, impacts, } \\
\text { concerns. } \\
\text { Introduce climate change and } \\
\text { expected changes in Florida. } \\
\text { Focus on changes that are relevant } \\
\text { for your community. } \\
\text { Present information through } \\
\text { graphics and include sources of } \\
\text { data. }\end{array}$ \\
\hline $\begin{array}{l}\text { Discuss climate change } \\
\text { without creating conflict }\end{array}$ & $\begin{array}{l}\text { Plan your initial activities carefully } \\
\text { to establish trust and build } \\
\text { relationships among attendees. } \\
\text { Include presenters that the } \\
\text { audience trusts and respects. This } \\
\text { may mean they bring conflicting } \\
\text { perspectives. } \\
\text { Consider whether the information } \\
\text { being presented is likely to conflict } \\
\text { with underlying values of your } \\
\text { audience. }\end{array}$ & $\begin{array}{l}\text { Is your audience likely to have } \\
\text { conflicting perspectives? } \\
\text { Can you frame the information in } \\
\text { a way that acknowledges different } \\
\text { values and multiple possible } \\
\text { outcomes? } \\
\text { Should you have an impartial } \\
\text { facilitator lead the session? }\end{array}$ & $\begin{array}{l}\text { Give participants a chance to } \\
\text { share their ideas and beliefs before } \\
\text { getting started. } \\
\text { Focus on shared values and various } \\
\text { community outcomes that may } \\
\text { occur as a result of adaption } \\
\text { planning. }\end{array}$ \\
\hline $\begin{array}{l}\text { Increase awareness } \\
\text { or knowledge of } \\
\text { vulnerabilities in the } \\
\text { community }\end{array}$ & $\begin{array}{l}\text { Determine the impacts to } \\
\text { which your community is most } \\
\text { susceptible. } \\
\text { Consider interactive ways to learn } \\
\text { more about specific risks and } \\
\text { vulnerabilities. }\end{array}$ & $\begin{array}{l}\text { What risks are specific to your area? } \\
\text { Which valuable and vulnerable } \\
\text { features of the community or } \\
\text { qualities of the life in the region are } \\
\text { most important to your audience } \\
\text { and should be prioritized for } \\
\text { protection? } \\
\text { What tools can you use to help } \\
\text { the group better understand the } \\
\text { vulnerabilities? } \\
\text { Which experts or community } \\
\text { members can share insights and } \\
\text { broaden the discussion? }\end{array}$ & $\begin{array}{l}\text { Have the group prioritize risks and } \\
\text { select those they wish to study } \\
\text { further. } \\
\text { Work together to understand } \\
\text { identified risks using tools and } \\
\text { data. } \\
\text { Discuss uncertainty and limitations } \\
\text { of projections. } \\
\text { Ask participants when the risk of } \\
\text { losing valued qualities is great } \\
\text { enough to begin to reduce that } \\
\text { risk. }\end{array}$ \\
\hline Increase motivation to act & $\begin{array}{l}\text { Determine example actions that } \\
\text { are reasonable for the community } \\
\text { and consider how participants can } \\
\text { play a role in implementing actions. }\end{array}$ & $\begin{array}{l}\text { What do your participants care } \\
\text { about? } \\
\text { What are your participants able to } \\
\text { do? } \\
\text { Are there any "small" projects that } \\
\text { are likely to be successful and } \\
\text { that can empower participants to } \\
\text { become more involved? }\end{array}$ & $\begin{array}{l}\text { Share examples of other } \\
\text { communities who are planning for } \\
\text { adaptation. } \\
\text { Focus on what has already been } \\
\text { achieved, and help participants } \\
\text { envision the next steps. }\end{array}$ \\
\hline
\end{tabular}




\begin{tabular}{|c|c|c|c|}
\hline $\begin{array}{l}\text { Agree upon shared goals } \\
\text { and expected outcomes }\end{array}$ & $\begin{array}{l}\text { Summarize previous steps taken to } \\
\text { prioritize risks. } \\
\text { Provide summaries to participants } \\
\text { in advance of a meeting. } \\
\text { Consider interactive methods to } \\
\text { build consensus around goals and } \\
\text { outcomes. }\end{array}$ & $\begin{array}{l}\text { Are all "voices" at the table? Which } \\
\text { perspectives are missing? Can they } \\
\text { be invited to the table? If not (such } \\
\text { as future generations), how will you } \\
\text { consider their interests? } \\
\text { Is there disagreement among } \\
\text { participants? If so, can you find } \\
\text { common interests by asking about } \\
\text { more general and universal goals, } \\
\text { such as security and environmental } \\
\text { quality? }\end{array}$ & $\begin{array}{l}\text { Ensure all participants have } \\
\text { background information on } \\
\text { impacts and risks. } \\
\text { Answer questions and update risk } \\
\text { information if necessary. } \\
\text { Include a diversity of stakeholders } \\
\text { in discussion. } \\
\text { Define planning goals, objectives } \\
\text { and expected outcomes. }\end{array}$ \\
\hline $\begin{array}{l}\text { Identify options or } \\
\text { potential strategies to } \\
\text { explore }\end{array}$ & $\begin{array}{l}\text { Bring partners to the discussion } \\
\text { who can speak to advantages } \\
\text { and disadvantages of potential } \\
\text { strategies. } \\
\text { Find relevant examples of other } \\
\text { communities who are using these } \\
\text { strategies. }\end{array}$ & $\begin{array}{l}\text { What additional information is } \\
\text { needed to identify all possible } \\
\text { strategies? } \\
\text { What strategies make sense for our } \\
\text { given situation? } \\
\text { What types of strategies build upon } \\
\text { our community's strengths and } \\
\text { existing resources? } \\
\text { What underlying values do these } \\
\text { options protect? Are these values } \\
\text { shared in this community? }\end{array}$ & $\begin{array}{l}\text { Generate options for adaptations. } \\
\text { Share lessons learned through case } \\
\text { studies from other communities. } \\
\text { Facilitate discussion about the risks, } \\
\text { costs, and benefits of each option; } \\
\text { explore the tradeoffs. }\end{array}$ \\
\hline $\begin{array}{l}\text { Select best strategies to } \\
\text { achieve goals }\end{array}$ & $\begin{array}{l}\text { Determine potential partners and } \\
\text { who can take on different roles for } \\
\text { specific strategies. } \\
\text { Explore community perceptions } \\
\text { about the different strategies. } \\
\text { Design interactive process to help } \\
\text { the group debate options and find } \\
\text { consensus. }\end{array}$ & $\begin{array}{l}\text { Are these strategies doable? } \\
\text { What barriers exist? } \\
\text { Who will be affected by these } \\
\text { actions? How? } \\
\text { What does the broader community } \\
\text { think? }\end{array}$ & $\begin{array}{l}\text { Seek alternative sources of local } \\
\text { knowledge and expertise. } \\
\text { Gather community or stakeholder } \\
\text { feedback on alternatives. } \\
\text { Weigh advantages and } \\
\text { disadvantages. }\end{array}$ \\
\hline
\end{tabular}

Table 2. Adaptation workshop framework. (Picketts et al. 2012 )

\begin{tabular}{|c|c|c|c|}
\hline Step & Purpose & Information presented & $\begin{array}{l}\text { Time } \\
\text { allocation }\end{array}$ \\
\hline 1. Introduction & $\begin{array}{l}\text { Clarify workshop focus; overview } \\
\text { activities; inform participants of their } \\
\text { key role in outlining strategy }\end{array}$ & $\begin{array}{l}\text { Definition and differentiation between adaptation and } \\
\text { mitigation; explanation of participants' role as experts } \\
\text { with local knowledge }\end{array}$ & $15 \min$ to $1 \mathrm{~h}^{\mathrm{a}}$ \\
\hline $\begin{array}{l}\text { 2. Understanding changes } \\
\text { in the climate }\end{array}$ & $\begin{array}{l}\text { Provide overview of past changes and } \\
\text { future temperature and precipitation } \\
\text { projections in the region }\end{array}$ & $\begin{array}{l}\text { Past climate trends and future scenarios (preferably } \\
\text { downscaled and presented by climate information } \\
\text { specialist) }\end{array}$ & $1-2 h^{b}$ \\
\hline $\begin{array}{l}\text { 3. Identifying local } \\
\text { impacts }\end{array}$ & $\begin{array}{l}\text { Link climate projections with actual } \\
\text { impacts in community (can be done in } \\
\text { focus groups or as one larger group) }\end{array}$ & $\begin{array}{l}\text { None, but requires careful facilitation by persons } \\
\text { familiar with adaptation and the community }\end{array}$ & $\begin{array}{l}1 \mathrm{~h} \text { (depends } \\
\text { on group size) }\end{array}$ \\
\hline 4. List of local impacts & $\begin{array}{l}\text { Combine outcomes of step } 3 \text { into a } \\
\text { single list (if necessary) }\end{array}$ & $\begin{array}{l}\text { Outcomes combined by organizers and presented to } \\
\text { plenary for discussion and finalization }\end{array}$ & $45 \min ^{b}$ \\
\hline $\begin{array}{l}\text { 5. Visioning an adaptation } \\
\text { strategy }\end{array}$ & $\begin{array}{l}\text { Prioritize impacts and recommend } \\
\text { implementation actions }\end{array}$ & $\begin{array}{l}\text { Framework for determining risks; potential sectors to } \\
\text { address impacts; documents where implementation } \\
\text { may be outlined }\end{array}$ & $90 \mathrm{~min}$ \\
\hline $\begin{array}{l}\text { 6. Final discussion, next } \\
\text { steps }\end{array}$ & $\begin{array}{l}\text { Encourage continued engagement } \\
\text { in adaptation planning and solicit } \\
\text { feedback on event }\end{array}$ & Feedback should guide further local adaptation & $30 \min ^{c}$ \\
\hline \multicolumn{4}{|c|}{${ }^{a}$ For neophyte communities a separate capacity building event may be preferable. } \\
\hline \multicolumn{4}{|c|}{${ }^{\mathrm{b}}$ Ample time for discussion should be allocated. } \\
\hline \multicolumn{4}{|c|}{${ }^{\mathrm{C}}$ Can encourage discussion to continue after formal workshop end. } \\
\hline
\end{tabular}

